\title{
Leasing as an effective tool for agricultural financing: within the example of Armenia
}

\author{
A. S. Mkhitaryan ${ }^{1 \bowtie}$ \\ ${ }^{1}$ European University, Yerevan, Republic of Armenia \\ ${ }^{\square}$ E-mail:mkhitaryan.aram@yahoo.com
}

\begin{abstract}
Through the decades' Armenian agriculture doesn't have sufficient growth. Technologies and methodology used by farmers are not sufficient for modern production creation. Financing system of rural areas are less effective as lack of stable income and low-price collateral doesn't let banking institutions to actively finance the sector. The main purpose of this study is to define problems of agricultural financing and determine leasing as an effective tool for agricultural financing. Methodology of this study is based on quantitative analysis among farmers and other borrowers to take out leasing role in financing process and other relevant issues. Empirical data analysis of different countries' experience and survey among local rural habitants were made to identify the most effective tools of agricultural financing. As a result, lack of effective financial and technological assistance has identified as an obstacle of agricultural development in Armenia. The importance of agriculture in the development of the country's economy was substantiated. The importance of public awareness in increasing the applicability of leasing has been identified. As a scientific novelty, the thesis of leasing as an effective financial tool for agricultural lending has been proven. The specifics of leasing efficiency for agricultural lending are explained. Absence of collateral as the only advantage of leasing was rejected.
\end{abstract}

Keywords: financing, agriculture, leasing, financial institutions, financial sources, MFIs.

For citation: Mkhitaryan A. S. Leasing as an effective tool for agricultural financing: within the example of Armenia // Agrarian Bulletin of the Urals. 2021. No. 03 (206). Pp. 81-91. DOI: ...

Paper submitted: 07.10.2020.

\section{Introduction}

Armenia is an industrial-agrarian country. The country is a predominantly rural and about $50 \%$ of its population engaged in agriculture which demonstrates also social importance of agricultural development. Crop production and cattle breeding is the main source of income for most of its rural population. At present, the vast majority of gross agricultural output (more than $98 \%$ ) is provided by the private sector. The economy of Armenia gives priority to small-scale agricultural production. In the structure of GDP, it accounts for: agriculture $-31.1 \%$, industry $-21.8 \%$, trade $-8.7 \%$, construction $-8.5 \%$, transport $-5.1 \%$, other sectors $-24.9 \%$. The main crops grown are melons and gourds, potatoes, wheat, grapes, fruit, essential oil, tobacco, and sugar beets. Livestock farming specializes in dairy and beef cattle breeding, sheep are raised in mountainous areas. Armenia is an important center of agro biodiversity. The rich agro biodiversity of Armenia is represented by wild relatives of grain crops, wild edible plants and a large number of plant varieties and animal breeds. Currently, a large number of plant species are grown in Armenia, including 6 types of crops, 366 fodder plants, 62 types of berries and 65 types of vegetables. In total, 521 plant species account for $16 \%$ of the total number of plants in Armenia. This reserve was created to protect the genetic diversity of wild, related forms of crops. In 2018 the value added in agriculture accounted for 13.7 percent of GDP; the gross agricultural output amounted to 1.8 billion USD, $46 \%$ of which ( 828 million USD) was generated from crop production, 54 \% (972 million USD) from livestock products. Russia is the major export market for beverages and crop and livestock commodities, with more than $70 \%$ of exports by value. This high dependence on Russian markets makes the agriculture sector highly vulnerable to the volatility of the Russian economy. The European Union (EU) receives less than $5 \%$ of the value of exports for these two commodity groups [1, p. 2].

According to Armenian Prime Minister speech dated on 23.03.2020, especially in the context of the crisis associated with the coronavirus, agriculture is becoming one of the most important areas of activity. Although this area has always been interesting, under the new conditions, the importance of agriculture is emphasized for several reasons. Firstly, food security issues are becoming increasingly relevant and important not only in the Republic of Armenia, but throughout the world. Secondly, agriculture is a sector where there are more preferable and effective opportunities for maintaining social distance. Thirdly, in Armenia there are wide opportunities for creating new jobs in agriculture and for ensuring self-employment. And fourthly, we believe that now is a very convenient time for carrying out such institutional reforms that were previously impossible for objective or subjective reasons.

Empirical data shows, that during pandemics, the agriculture sector remains the most important economic sector, for the poor in many developing countries. Closed borders and limited international commerce accelerate local agricultural 
and rural growth. In contrast, many researchers and international organizations like UNDP, FAO have analyzed different illnesses and pandemics impact of agricultural sustainability and growth. Different impact elements were taking out on agricultural production such as reduction in area of land under cultivation, declining yields and livestock, loss in agricultural skills [2, p. 9]. We see, that decline in food production and farmers' production is expected during pandemics which will impact also on food security. At the same time, food consumption is also reducing in all surviving families. The facts show that it is important during pandemics to gather more families and entrepreneurs in agriculture with Government supporting programs and effective financial instruments to secure food deficit and increase farm production. One of the key issues of agricultural development remains access to effective financial resources.

Lack of access to financial resources is a key obstacle for poor countries to develop. In the second quarter of 2020, Armenia had 17 commercial banks and 42 microcredit organizations, 4 of which are registered as specialized leasing organizations, but one of them in fact is not functioning. Only one bank out of 17 is specialized in the financing of rural communities (ACBA Credit Agricole Bank), as well as several credit organizations were also actively involved in it. Commercial banks, in general, were not interested to provide financial services in rural areas because of different reasons. Farms and small food processing companies have lack of sufficient collateral to obtain a loan for their future growth and projects. In emerging countries rural habitants and entrepreneurs can't find any other affordable financing which can be substitute to classic bank financing. In this situation, it becomes very important to create a financial instrument which will partly or fully cover collateral problem. Leasing is a financing tool that overcomes this idea.

Leasing as a modern financial instrument is used in early 50 s in USA. After that, year by year it becomes more popular and starts to serve as an alternative for car loans and equipment and technology acquisition targeted business loans. Leasing is a financial instrument which can cover collateral issues for many of those rural area borrowers as the lease object itself becomes as a collateral. If the lease object is general equipment or technology, it becomes easier to sign the contract as leasing object becomes more liquid item and easier to sell or provide secondary leasing in case of lease contract failure. From economic perspective leasing is a contract between lessor and lessee where lessor provides lease equipment to lessee (in classic leasing contract lessee chooses lease object) for a certain period of time and gets lease payments from lessee [3, pp. 7]. From accounting standards leasing contract is an agreement where lessor provides lease object to borrower for a certain period of time for using and gets regular payments in regular dates as a compensation. In general, there are financial and operational leasing types. A finance leasing agreement as a rule is long term and borrower buys lease equipment in the end of the contract. In other words, during finance lease the borrower leases equipment with the purpose to own it after the contract. In contrast, operational lease is a short-term contract and in general the lease object in the end of the lease agreement stays for lessor's ownership. In this case borrower doesn't think about to buy the lease object in the end of the contract. As
Аграрный вестник Урала № 03 (206), 2021 г.

per Breadley, et al., there are three types of leasing: direct, when the manufacturer and lessor becomes the same side of the contract, operational, when the maintenance and other general expenses of lease object falls on lessor and the sides of the contract can cancel leasing agreement before the expiry of the contract, and the third and last one is financial leasing, which is the most common one when the lessee implies all the costs of lease object itself and in the end gets all the rights of it [4, pp. 548-551].

In Armenia, first leasing contracts started in early 2000s with creation of Agroleasing company. In 2003, the company registered in central bank of Armenia as a leasing credit company as the legislation changes and lease provision becomes a licensed activity. It is not a coincidence that first lease agreements in Armenia started in agricultural sphere as that was the most demanded sector of the economy for a modern financial instrument as the classic ones doesn't work anymore. Till nowadays, leasing plays a vital role in agricultural financing in Armenia as it becomes also an instrument which Government uses for implementing state support programs. It is a fact that leasing has been successfully implemented as a financial instrument which helps financing farmers and rural habitants with better conditions rather than classic financial instruments. Having awareness about benefits of leasing and information about specificities of this product farmers better use advantages of leasing compared with traditional banking loans and also gets more competitive interest rates [5, pp. 47-60].

Having several advantages like additional non-financial services from leasing companies and irrefutable purpose of financing makes leasing an important financial instrument for different sectors of economy and especially for rural area borrowers which end to different obstacles during when applying for a regular loan. For farmers, sometimes leasing becomes the only way to get financing as in their conditions they cannot access to bank loans. In addition, down payment and first investment of the project is also lower for leasing as the required lease object is easier controllable rather than cash money. In many countries' creditor rights are weak and they need to pass a long court procedure to take possession of collateral and in terms of leasing the lessor is the owner of the lease object without going to court. In contrast, in Armenia and in many CIS countries it takes the same length of time to prove the right to get the lease object back which doesn't let to use benefits of leasing. Thus, taking into consideration of all the arguments mentioned, it is important to mention that there is no clearly applicable methodology for evaluating the effectiveness of leasing for different parts of the contract and no techniques focused on financial benefits and effects for the lessee who have been taken leasing product [6, pp. 1104-1106]. At the same time, Governments of emerging countries which accept benefits of leasing needs to change their regulatory more familiar for lease contracts and specially to adopt judiciary system for making easier taking back lease object from borrowers who doesn't payback lease payments on time.

One of the specificities of the agriculture growth in the Post-Soviet countries is the necessity to invest into production development, mainly in buying modern machinery and equipment and provision of it with acceptable financial terms and conditions. All this leads to the necessity to seek alternative ways of financing investments, mainly leasing. 
The objective of this paper is to analyze potential of leasing as an effective tool for rural area development financial tool, as an alternative for classic agricultural loans and microloans. The paper defines reasons why banks doesn't actively finance rural entrepreneurs and farmers and its advantages. Apart from this, the work provides overview of leasing utility in the rural area financing sector within its framework. The paper concludes by providing recommendations for enhancing Government support to expand access to leasing in rural areas. Three general objectives of this study are to:

- identify reasons of why banks don't want to finance agriculture;

- evaluate benefits of leasing for government support of agriculture;

- evaluate advantages of lease financing for rural habitants.

The economic incentives for leasing as being an effective tool for machinery, equipment and other objects for farmers and other rural area habitants are primarily lack of information about leasing product in general. The advantages of leasing such as absence of collateral, tax related, additional benefits from manufacturers in case of leasing projects are important on decision making process of clients. But results of survey shown that only classic advantages are not fair enough to stop on choosing leasing. Other benefits such as discounts from manufacturers can play important role in leasing promotion. The current issues of rural habitants to access financial resources are equivalent important in the leasing decision. These factors, and associated incentives are identified in this study through a survey of selected issues among rural habitants in Armenia.

\section{Methods}

Different theoretical and empirical methodologies are used to meet the specific objectives in this article the paper analyses the impact of leasing as a financial tool for rural area financing and development. At the same time, multiple Government support projects were analyzed to understand whether leasing plays role in Government projects for financial support of borrowers. For this purpose, mainly to meet first two objectives of the article, a questionnaire is prepared and randomly sent to rural habitants and farmers. For analyzing facts about leasing development and its usage in RA, input results of quantitative analysis to SPSS were made to get statistical information within the answers of the questions. Some statistical data used in this paper were obtained from the Armstat and official websites of Armenian banks and MFIs, foreign governmental and other official websites. To meet the third objective, alternative financial tools and mechanisms were discussed on this paper to find out substitutes of leasing in financial market which have been used in different countries. For this purpose, analysis of articles was done to discover any long-run benefits of leasing for rural development.

\section{Results}

Nowadays, agriculture is much more than farming; it is becoming more and more integrated with other sectors of the economy, and this integration requires optimization through the use of digital technologies. E-agriculture is the use of information and communication technologies in agriculture, including crop production, livestock, fisheries and forestry. It implies the use of both traditional technologies, such as radio, television and mobile phones, as well as the latest digital technologies, such as unmanned aerial vehicles, satellites, sensor technologies, the Internet of things and machine communications. The country's agricultural sector can take advantage of the use of digital technologies, provided that a strategy is clearly defined at the national level, the development of which will involve stakeholders from the public and private sectors, smallholders and family farmers, non-governmental organizations and the scientific community, as well as country's rural development goals taken into account [7, p. 18]. According to FAO data, the goal of e-agriculture is to develop agriculture and rural areas through the application of improved information and communication processes. This includes the creation of concepts, design, development, evaluation and application of innovative methods of using information and communication technologies in the agricultural sector, covering the entire food system [8].

Leasing is at a poor stage of development in Armenia. Comparing with developed countries, leasing transactions in overall economic transactions are 10 times less of the average, and 5 times less in comparison with developing countries. However, the pace of development is growing year by year. As the experience of international countries shows, the development of leasing begins with the classic rent. The next step is to get a loan to buy equipment [9, p. 38]. Leasing in the RA was first defined by the Civil Code of the Republic of Armenia, which entered into force in 1999. Civil code defines, that the lessee undertakes to obtain the mentioned property of the lessee from the seller determined by the lessee and to transfer it to the temporary use of the lessee for a fixed fee [10, pp. 677-685]. Looking through the leasing in developing countries, we see that leasing is interesting to all parties of the contract: A producer of equipment that increases sales through leasing, a client who spends least possible financial resources gets the right to use the necessary equipment, and the government can use leasing for state support projects and be sure for the right purpose of used funds. As in Armenia, the main areas of leasing are mining, leasing of construction equipment, leasing of agricultural machinery and leasing of vehicles. Due to the juridical gap, only financial leasing is in effect in Armenia. The development of financial leases is also facilitated by state regulation of investment policies, in which the formation of tax and customs privileges for participants in financial leases and the introduction of accelerated amortization of leased property play a crucial role. In general, this has a beneficial effect on the country's economy, contributing significantly to the regeneration of fixed assets in industry and agriculture [11, p. 32]. What concerns to latest legislative improvements on leasing in Armenia, on June 22, 2020, a package of legislative amendments on leasing was adopted, which excluded some of the obstacles associated with the taxation of the leased property, property taxation issues were removed, as well as definition of secondary leasing, subleasing and other leasing details were fixed in tax code and civil code. This changes can significantly increase the quantity of leasing contracts and affect on efficiency of financing of agriculture as main problems arising of agricultural financing covers leasing instrument (lack of collateral, inefficient monitoring of purpose of financing etc.). 
Different countries' experience has been analyzed to understand specificities of agricultural growth and its financing obstacles. Experience of Russia, France, Serbia, India, USA, Ukraine, Kyrgyzstan and Armenia were discussed.

According to preliminary data from the Ministry of Agriculture, in 2019, agricultural production in Russia grew by more than $2 \%$ by 2018 , when the industry experienced a decline of $0.2 \%$. In 2019, the export of Russian agricultural products amounted to about 25 billion USD, which is slightly less than in 2018 (25.8 billion USD), but higher than the plan, which was set at 24 billion USD. In contrast, Minister of Agriculture of Russia D. N. Patrushev noted that in 2020 an increase in livestock production is expected, including due to milk and meat [12]. A key attention is dedicated to leasing market which is a key indicator of the Russian economy. Leasing is considered as an efficient means of business assistance and an effective tool of sustainable development, as well as a way of obtaining credit income and renovating main capital. At this phase of Russian economy development, it is vital to work out the relevant order of transactions and the Central Bank propose that the leasing business should draw amendments to the existing regulations in order to create advanced control standards for leasing operations $[13, \mathrm{p} .1]$.

As in France, it has a useful agricultural area of 27 million hectares, or $15 \%$ of the UAA of the EU; moreover, it represents $18 \%$ of the value of agricultural production in the European Union. By cultivating nearly 28 million hectares and contributing $17 \%$ to the value production of the European Union carried out in agriculture, France remains the main agricultural country in Europe. This increase in productivity is due to the genetic improvement of varieties, better crop protection and more efficient agronomic practices. In contrast, agricultural production in France contributes to the degradation of the environment. It affects air quality by generating $20 \%$ of national greenhouse gas emissions, due to the use of fertilizers, heated greenhouses, strong mechanization, etc. [14, p. 16]. Many leasing companies in France are united in a national association (ASF). Six lessors held $80.9 \%$ of leasing operations in the country, while the first two lessors, SG Equipment Finance and BNP Paribas Lease Group, accounted for $47.7 \%$. The challenges France is struggling with in agriculture are the achievement of food and nutritional security and the development of sustainable agriculture for the period from 2019 to 2024. To do this, in particular, to promote such sustainable forms of agriculture as agro-ecology; access to quality food, drinking water and adequate sanitary and hygienic conditions $[15, \mathrm{p} .7]$.

Rural segment has a significant role in Serbian economy. The portion of farming, forest industry and fishing in net worth included 2016 was $6.5 \%$. It employed $18.5 \%$ of the total number of engaged persons in 2017 and has a share of $7 \%$ in total export. Moreover, if we add data for manufacture of food products, beverages, tobacco, then the share of such production in Serbian export is much more considerable, around $22 \%$. As per Popovic, et al., agriculture in Serbia is characterized by insufficient profitability due to certain seasonal and extensive production cycle, weak specialization of production, low capacity utilization, low turnover ratio, higher exposure to natural hazards in latest years, and inefficient financing mechanisms. Though there are diverse financial sources, their condi- tions are badly designed and are not satisfying needs of agricultural producers. Agro-crediting in Serbia is not even close to its full potential. Agricultural production is still influenced by the state support through subsidies from the agrarian sector, but still this doesn't have sufficient role [16, pp. 66-70]. As per Popović, et al., only 5 banks finance agricultural sphere in Serbia because banks are not informed about the real potential of this segment of the economy and also risks which cover agricultural sphere are also not familiar to them. In agriculture business analysis is complicated and needs to use more knowledge about food processing and other agricultural processes and technologies. Banks mention too many unresolved issues and uncertainty about the ability of agricultural producers and processors to meet their obligations and absence of high-quality collateral [17, p. 130].

O. Eremina found out, that agriculture is a dependence on climatic conditions, a long reproductive cycle, low profitability of agricultural production, borrowing of commodity producers, their insufficient state support (compared with the USA and EU countries), the price disparity of agriculture and its branches, a significant need for short-term and long-term borrowed resources [18, p. 162]. For banks, it is clear that providing significant funding over long periods increases risk taking and requires specific skills to manage these risks at a reasonable cost. As a result, financial institutions are often reluctant to provide such funding. In the past, to improve the supply governments have frequently intervened in term loans through rural development banks or various credit programs. However, following poor performance, both in terms of clientele and the viability of these directed loans, most of these credit programs were interrupted and several rural development banks filed for bankruptcy [8].

According to A. Das, \& N. M. Patnaik, high cost of delivered services, lack of affiliate networks, perception of low profitability in agriculture, information skewness, high levels of rural poverty or low levels of farmer education, lack of collateral and financial literacy are certain of the reasons why lenders are not interested to finance agriculture in India. The same problem exists in different regions in Asia. But most of banks' managers are seen to blame high degree of uncontrolled production and price risk for not financing agriculture. Thus, farmers have to lean on non-institutional financial organizations. The significant sources of non-institutional credit are traders and commission agents, landlords, money lenders, friends and relatives etc. Mainly all payments are made through cash. Lack of regular price information, commission agents and product quality are some of the issues connected with the input side while payments receivable by farmers are more often than not ridden with delays is the obstacles bound to output aspect $[19$, p. 6].

In contrast, the main driver for the recent activity of interest in international investment in food production appears to be food security and a fear arising from the recent increase of food prices and possible supply shocks that may occur on global markets for foods supplies or agricultural raw materials has become riskier [20, p. 5]. This can be also up to date during COVID-19 pandemic as food security becomes modern issue in many countries in the beginning of pandemic. 
Despite its economic and political importance, the agricultural sector of Armenia still faces a number of restrictions that limit its full potential. Agriculture growth slowed in response to the Global Finance Crisis (GFC) in 2009 and the Russian recession in 2013-2014, but though it seems that it will have a big negative effect, these events did not lead to sector reduction. The only contraction from 2004-2015 was due to a severe drought in 2010, which resulted in a sharp fall in real agriculture GDP [1, p. 3].

As per R. Kloeppinger-Todd \& M. Sharma, study made globally in many countries shows, that financial institutions have demonstrated low interest in rural area lending for different reasons. Particularly, many rural households were located in farther parts of the regions and often so dispersed that lenders need to make bigger efforts and costs to provide services to them. Another issue related to rural area financing is weather and climate risks, making it hard for MFIs and banks hedge the financial services or operate profitable insurance another issue is lower educational level among borrowers. Finally, financial institutions hardly calculate agricultural business risks within its specificities [21, p. 2].

The reasons why financial institutions consider agricultural financing to be unprofitable may be different. The main reason in Armenia, still, is the high risk correlated with weather and climate conditions, diseases. In many cases, managing these risks is unpredictable and hard. Currently, a pilot experiment is underway in Armenia to ensure crop insurance according to weather conditions, which can shorten risks and make agricultural financing more profitable and efficient. Other reasons may be the high operating costs, since the average volume of agricultural loans is much lower than that of industrial or business loans, which boost the operating costs, as well as their distribution in different rural communities. Moreover, loan debt collection and contract implementation procedures are particularly taking long time in rural districts of Armenia. The restrictions faced by the non-bank lending realm are mainly related to regulations. The lack of regulation for MFI lending institutions, combined with the official idea that only banks can take out deposits as their daily activities, makes this sector underdeveloped and unable to serve this market segment. In case of leasing, the regulation of VAT leads to the fact that leasing is less attractive to customers than a regular bank loan. Lack of the adjustment or lack of appropriate adjustment leaves negative impact on VAT, but due to the nature of the agricultural sector it is even more noticeable.

To conclude, several global reasons about lack of financial institutions to finance rural habitants can be taken out. First$l y$, very small amount of loans in different parts of the region brings to huge operational costs. Second is hardly managing risks which face farmers, mainly weather and climate risks, which insurance companies in emerging countries doesn't cover or cover with non-affordable price. Another problem is low profitability of agricultural business, which doesn't cover higher interest rates for micro and small loans provided for farmers or rural area living individuals. Lack of collateral has been considered to be an obstacle for rural habitants to be financed. And one of the biggest issues is low educational level of rural area habitants. Many MFIs though input technical assistance with financing but this also not always works.
In the situation of the development of the post-industrial economy, the way of the financing of reproduction of the material and technical base of enterprises in the agrarian sector has experienced some considerable changes. One of the important issues of active technical upgrade of fixed assets in the agricultural sector is a significant deficit of funds that could be dispense for ensuring this process.

State support of farmers and food processing companies should be based on development of more effective method for allocating budgetary funds. Steps done for increase of leasing instrument usage in agricultural sector should function based on the market competition and involving private leasing companies as well as state leasing companies too. In order to strengthen cooperation with agrarian enterprises, the government should foster private leasing companies by partially compensating the leasing rate of interest at a level that is the size of the Central Bank's discount rate; by way of partially compensating the value of the leased asset after preliminary payment by the lessee at the rate that is reciprocal to the advance payment but not more than $30 \%$ [22, p. 7].

An exogenous shock for Armenian agricultural sector is considered to be COVID-19 pandemic, which closes borders with external world and farmers could not plan export of their production.

Respondents believe that the pandemic had a moderate negative impact on their activities. From the table above we see, that pandemic has some negative impact on $70 \%$ of responders. Only some small farmers who sells its production in local markets haven't been negatively impacted from the pandemic.

Armenian Government started to implement several programs to save the situation by subsidizing agricultural loans. Another program was co-financing the agricultural cooperatives. The experience of implementing the idea of cooperation shows that agricultural cooperatives can solve many significant problems in the agricultural sector of Armenia, such as overcoming difficulties in selling agricultural products, using agricultural equipment, providing resources (fuel, seeds, fertilizers, etc.). Thus, one of the main goals of the government in this sector should be to increase the participation of households in agricultural cooperatives [23, pp. 121-122].

Because of COVID-19 pandemic, Government of the Russian Federation approved a rule dated in 03.06.2020 No. 811 "For the provision of subsidies from the federal budget for compensation of losses of Russian leasing organizations when providing the lessee with a discount on advance payment under leasing contracts for specialized equipment". The program provides lessee with a one-time discount on advance payment in the amount of $10-15 \%$ of the price of different machinery and equipment, depending on the region of supply. The state, in turn, fully compensates leasing companies for losses due to the provision of a discount. For the implementation of this measure of state support in 2020, approximately 53 million USD were provided. The leasing subsidy will make it possible to supply 10.5 thousand units of machinery and equipment this year, of which 2.5 thousand units at the expense of additional financing. It's important also to note that starting from first January 2020, Russia plans to suspend integrated development of rural areas, the program for subsidizing agriculture equipment manufacturers and introduce a system of preferential leasing with state support for Russian plants to sell agricultural machinery by leasing [24, p. 1]. 


\begin{tabular}{|c|c|c|c|c|c|}
\hline & & \multicolumn{4}{|c|}{ COVID-19 pandemic impact on rural habitant } \\
\hline & & Frequency & Percent & Valid Percent & Cumulative Percent \\
\hline \multirow{5}{*}{ Valid } & No & 15 & 30.0 & 30.0 & 30.0 \\
\hline & Yes, has left a significant negative impact & 24 & 48.0 & 48.0 & 78.0 \\
\hline & Yes, had a negative effect on the average size & 7 & 14.0 & 14.0 & 92.0 \\
\hline & Yes, left little impact & 4 & 8.0 & 8.0 & 100.0 \\
\hline & Total & 50 & 100.0 & 100.0 & \\
\hline
\end{tabular}

Table 2

Differences between financial leasing and commercial loan

Leasing

Credit

1. As a rule, financial leasing does not presuppose the 1 . From the moment of receiving the loan until its repayment existence of collateral, as collateral is the subject of the lease, deadline, the borrower demands a corresponding collateral which belongs to the lessor during the entire period of the which can be sold in case of non-fulfillment or improper contract

fulfilment of obligations by the borrower

2. Leasing rent schedule can be based on a mutually agreed schedule

2. The terms and conditions of the loan repayment are not aimed at the borrower's interests but at ensuring the bank's liquidity ratio

3. Preferential period, is before receiving the subject of 3 . In general, there is no grace period for a loan with leasing does not make payments to the leasing company seasonal payments

4. Simplicity and speed of registration up to one day

5. Leasing can be provided for both short-term, mediumterm and long-term

A similar project is implemented by the minister of the Kyrgyz Republic M. Abylgaziev called "Financing of agriculture" which aimed to improve the breeding cattle and elite seed production. The total amount of the project in 2020 will exceed 70 million USD. This will allow not only enlarging existing farms, but also increasing potential export and preserving food security. A part of the project will be done using leasing financial instrument. As for leasing financing, a study of the leasing market showed that international organizations also have an interest in supporting leasing in Kyrgyzstan [25, p. 1]. For example, the Asian Development Bank is implementing a program to support women's entrepreneurship, in which it pays attention in raising the awareness of women entrepreneurs about leasing. In addition, the study showed that GIZ also provides "technical" support to facilitate the development of leasing in Kyrgyzstan [26, p. 43].

At the first steps of the development of market relations of Ukraine, the need to renew the equipment and organize the availability of progressive technologies and competitive production, especially in the leading sectors of the economy, depends on the frequent usage of leasing transactions. Considering that in the conditions of the economic crisis, the possibility of access of local enterprises to classic lending products to fill in required financial resources becomes very difficult and in the unprofitable conditions, and it makes attention to a financial instrument such as leasing which can be very necessary. The development of the leasing market in Ukraine requires a transparent, consistent legislation. Unfortunately, the legal regulation of leasing activity in Ukraine is far from being perfect. Norms of legal acts are not effective and sometimes rejects each other $[27$, p. 25]. Actual situation of the development of leasing requires difficult combination of legal, organizational and economic basis for the provision of state support
4. A larger package of documents is required when submitting for a loan

5. Commercial loans are provided for up to 5 years

for leasing activities at the legislative level. When developing tools and implementing state regulation tools and supporting leasing activities, it is essential to measure not only the size, but also the direction of use of these tools. International experience and tools for regulating leasing activities should also be beneficial. A similar to Russian and Kyrgyzstan countries' experiment is used in Armenia. Starting from 2017, Government of Armenia started to partially subsidize percentage rates of agricultural loans and leasing in Armenia. Government wanted to ensure a very low percentage on leasing so that the villagers, as well as agricultural companies, cooperatives, communities, can take advantage of the program.

From the discussion we see, that most of the countries run governmental support programs for agricultural growth expansion, and some of them use leasing as a financial instrument for implementing support programs. The reasons can be different. Banks find uninteresting to finance agriculture, which becomes one of the main factors for governments to intervene. The study showed also that the pandemic had a negative impact on rural residents and farmers, which means that taking into consideration the food security issue, strategic importance of agriculture, and the financial vulnerability of the rural population, there is a need to develop effective financial and non-financial tools to alleviate the situation.

Below, leasing specificities and possible government support programs in Armenia were discussed. When planning the purchase of new fixed assets, the question undoubtedly arises as to what financial means can be used to accomplish the idea. Today, the two simplest options for this issue are credit lending and financial leasing. In many cases it is easier to get financed through leasing rather than through credit. This is because leasing makes it possible to obtain equipment or technology with little initial capital (1/3 or less) or change the type of 
product that is not in demand returning the equipment to the leaseholder, in case of the classic leasing agreement. This is the main attraction of leasing, which is a substantial feature compared to the other types of lending.

From table 2 several advantages of leasing transactions were shown. In some countries, leasing organizations also provide tax benefits for the lessee [28, p. 23]. Without making large initial investments, the leaseholder gets the opportunity to replace old equipment with new ones and produce competitive production. As for government many countries have adopted a leasing development policy because they see it as a modern way to boost investment activity. Leasing contributes to the collection of funds for investment activities through its mechanism ensures the insured use of investment resources to upgrade production. For suppliers, leasing is an opportunity to sell the product. They sign a partnership agreement with leasing organizations and provide discounts to ensure a stable sales mechanism for their products $[29$, p. 30]. These advantages are only few of those, which can be used to develop competitive financial product. As we see, some countries use leasing advantages for supporting agricultural or overall economic growth. Some countries, such as Ukraine, use limited opportunities of leasing for state support projects as at current stage there are legal and regulatory problems of using leasing in its full potential. In Armenia, the situation with leasing regulation was also poor, but in latest years several big changes have been organized concerning leasing regulation which will help its future effective use.

In Armenia, from the first signs of the pandemic, when the government began to think about implementing economic support programs, leasing began to be considered as an effective financial tool for implementing support programs. It was proposed to finance complete projects through leasing, i.e. to consider the whole greenhouse as a subject of leasing, ie not the technological part of the greenhouse economy. The same thing started to apply to refrigeration farms, also to non-agricultural projects. The latter confirms the importance of the role of leasing, especially in financing rural communities. Ac- cording to the official data of the Ministry of Economy, there is currently a state support program for leasing concerning the purchase of agro-food equipment in Armenia. During the six months of 2020, only 284 leasing transactions were carried out under state support programs, which is $20 \%$ more than last year. 2019 As of the end of 2010, the loan portfolio in Armenia is about 8 milliards of USD, of which 600 million USD are property acquisition deals. But leasing transactions amount to 40-60 million USD. In fact, most of the equipment, production lines, and thickeners are financed through loans, not leasing. In fact, the demand for leasing may be 10 times higher than it is now. In March 2020, the program of lease and agricultural loan percentage rate subsidization is overwritten and the percentage rate started to be subsidized by $100 \%$ till end of 2020, so farmers get $0 \%$ interest rate financing. In 2017, in the case of leasing of agricultural equipment, the farmer (or enterprise) paid $2 \%$ instead of $9 \%$, and in case of leasing for processing equipment (for example, pasteurization machines for milk or for cooking eggplant) $-4 \%$. For loans, minimum interest rate was $5 \%$. Leasing has advantages in terms of interest rate as Government evaluates potential of leasing as an effective financial tool. Now these financing becomes completely interest-free for borrowers. In addition, all interest on micro agricultural loans up to 2 thousand dollars were also subsidized to farmers, in case banks and MFIs put an interest rate of maximum $13 \%$ and a period of up to two years. New support measures are also provided for cooperative loans. The state provides $10 \%$ co-financing to agricultural cooperatives, and $10 \%$ co-financing to other economic entities, but not more than 20000 USD.

The quantitative analysis is made to evaluate benefits of leasing for government support of agriculture and advantages of lease financing for rural habitants. Survey consists of 25 questions which discovers issues related to the identification of important elements of lending, as well as the applicability of leasing among farmers. It is made via private messaging to specific clientele among farmers and rural habitants of different regions as well as via face to face visits to clients. Overall

Table 3

Correlations between different measures of responders ${ }^{1}$

\begin{tabular}{|c|c|c|c|c|c|c|}
\hline & & Age & $\begin{array}{l}\text { Agricultural } \\
\text { employment }\end{array}$ & $\begin{array}{c}\text { Financial } \\
\text { service used }\end{array}$ & Gov. Program & $\begin{array}{c}\text { Individual or } \\
\text { cooperative }\end{array}$ \\
\hline \multirow{3}{*}{ Age } & Pearson Correlation & 1 & -.220 & -.168 & -.132 & .097 \\
\hline & Sig. (2-tailed) & & .125 & .245 & .360 & .505 \\
\hline & $N$ & 50 & 50 & 50 & 50 & 50 \\
\hline \multirow{3}{*}{$\begin{array}{l}\text { Agricultural } \\
\text { employment }\end{array}$} & Pearson Correlation & -.220 & 1 & .028 & .183 & .169 \\
\hline & Sig. (2-tailed) & .125 & & .848 & .203 & .240 \\
\hline & $N$ & 50 & 50 & 50 & 50 & 50 \\
\hline \multirow{3}{*}{$\begin{array}{c}\text { Financial service } \\
\text { used }\end{array}$} & Pearson Correlation & -.168 & .028 & 1 & .069 & -.136 \\
\hline & Sig. (2-tailed) & .245 & .848 & & .636 & .347 \\
\hline & $N$ & 50 & 50 & 50 & 50 & 50 \\
\hline \multirow{3}{*}{ Gov. Program } & Pearson Correlation & -.132 & .183 & .069 & 1 & .000 \\
\hline & Sig. (2-tailed) & .360 & .203 & .636 & & .997 \\
\hline & $N$ & 50 & 50 & 50 & 50 & 50 \\
\hline \multirow{3}{*}{$\begin{array}{l}\text { Individual or } \\
\text { cooperative }\end{array}$} & Pearson Correlation & .097 & .169 & -.136 & .000 & 1 \\
\hline & Sig. (2-tailed) & .505 & .240 & .347 & .997 & \\
\hline & $N$ & 50 & 50 & 50 & 50 & 50 \\
\hline
\end{tabular}

${ }^{1}$ All respondents are small and medium farmers from different regions of Armenia 
50 farmers answered to the questions. Most of the responders were from 29-60 years old (66\%), $62 \%$ were male and $38 \%$ female. We have responders from all 10 regions of Armenia, mainly $32 \%$ from Ararat region, $20 \%$ from Shirak region, $18 \%$ from Armavir region and $30 \%$ left from other regions. Occupation of the responders was split $50 \%$ of responders were crop production, $32 \%$ agricultural and food processing and $18 \%$ livestock breeding.

The combination of the questions in the tables indicates that people in different age groups have a higher level of awareness than others; they tend to make a different choice than the current active farmers. Pearson correlation shows, that older age group responders appreciate the cooperative idea, in contrast to young farmers who prefer individual agriculture. The highest correlation $\mathbf{. 1 6 9}$ is registered agricultural employment and choice between individual vs cooperative type of farming. Research conducts that those, who own small plots of land or farms are also inclined to the idea of cooperatives.

On table 4 we see comparison of age and government support program which is the most efficient as per responders. Data shows that most of the responders made importance on interest rate subsidy program. Only one responder answers leasing program as the most important state support program. Taking into consideration the data, by analyzing for which age group leasing is most desirable, it is possible to do the right marketing specifically for that target group. For example, if the state tends to support small farmers or senior age experienced farmers, leasing can develop the idea of activating cooperatives (taking into consideration the data from table 3 ), thus solving two problems at once in terms of meeting the needs of specific customers, increasing the applicability of leasing.

Based on literature review and experience of the countries discussed in the article about leasing advantages and alterna- tives to banking loans, an attempt was made to study the most important element of borrowing money for farmers. Half of the responders $(50 \%)$ answered low interest rate as the most important element in borrowing process. In contrast, absence of collateral was chosen by the least number of respondents. A number of researches shows absence of collateral as one of the hardest problems for farmers and rural area habitants for crediting, but we see, that this problem becomes less important for borrowers. This means absence of collateral cannot be chosen as sole key advantage of leasing for its promotion, other advantages need to be specified too.

According to table 6 data, major part of responders answered negatively for possible alternatives of crediting. It means, that there are not so many ways to get financial resources for farmers and rural habitants from other sources besides banking loans. Leasing can play a role of an alternative financial instrument for classic financing and help borrowers to diversify their choice.

From the table $7 \& 8$ we see, that the vast majority of respondents did not use leasing. The further question strengthens our assertion that the respondents are not familiar with leasing as a financial product, especially its features. Most of them even didn't hear about government support program through leasing even though government used different resources for its promotion. Only $10 \%$ of the responders answered positively for using leasing and most of them seems to use leasing within governmental support instrument. Leasing companies and banks doesn't provide any specific advantages to borrowers for choosing leasing product such as special discounts or privileged warranty which are usually estimated from manufacturers to leasing providers, or tax/accounting benefits which are considered from specific products or types of clients.

Cross tabulation of the age of responders and government support program importance Possible Government Support Programs

Free dose of fuel, elite seeds
Co-financing of smart cattle ranches, greenhouses and other programs

\section{Interest rate subsidy}

State support program through leasing

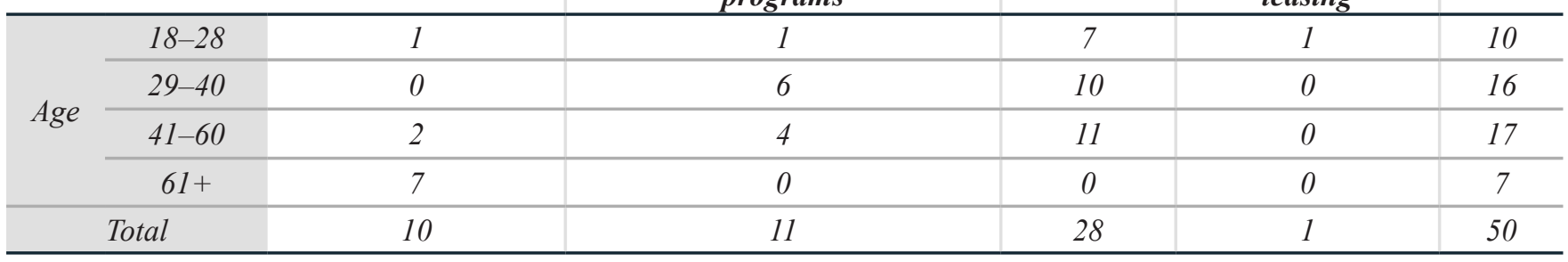

Table 5

Importance in loan provision procedure

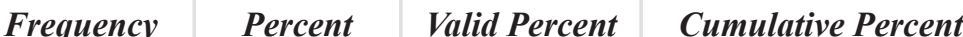

\begin{tabular}{cc|c|c|c|c}
\hline \multirow{5}{*}{ Quickness } & 7 & 14.0 & 14.0 & 14.0 \\
\cline { 2 - 6 } Valid & 25 & 50.0 & 50.0 & 64.0 \\
\cline { 2 - 6 } & Low interest rate & 8 & 16.0 & 16.0 & 80.0 \\
\cline { 2 - 6 } & $\begin{array}{c}\text { Seasonal payments } \\
\text { Lack of collateral or profitable Loan / } \\
\text { collateral ratio }\end{array}$ & 5 & 10.0 & 10.0 & 90.0 \\
\cline { 2 - 6 } & \begin{tabular}{c} 
Technical support \\
\cline { 2 - 6 }
\end{tabular} & 5 & 10.0 & 10.0 & 100.0 \\
\hline
\end{tabular}


Alternatives to bank loans

\begin{tabular}{ccc|c|c|c} 
& & Frequency & Percent & Valid Percent & Cumulative Percent \\
\hline \multirow{4}{*}{ Valid } & $\begin{array}{c}\text { Friend, acquaintance, } \\
\text { debt from a friend }\end{array}$ & 7 & 14.0 & 14.0 & 14.0 \\
\cline { 2 - 6 } & Grant programs & 7 & 14.0 & 14.0 & 28.0 \\
\cline { 2 - 6 } & Involvement of partners & 8 & 16.0 & 16.0 & 44.0 \\
\cline { 2 - 6 } & No alternative & 56.0 & 56.0 & 100.0 \\
\hline Total & 50 & 100.0 & 100.0 & \\
\hline
\end{tabular}

Table 7

Awareness of leasing features \begin{tabular}{l|l|l|l|} 
Frequency & Percent & Valid Percent & Cumulative Percent \\
\hline
\end{tabular}

\begin{tabular}{c|c|c|c|c|c}
\hline \multirow{3}{*}{ Valid } & Yes & 12 & 24.0 & 24.0 & 24.0 \\
\cline { 2 - 6 } & No & 38 & 76.0 & 76.0 & 100.0 \\
\cline { 2 - 6 } & Total & 50 & 100.0 & 100.0 & \\
\hline
\end{tabular}

Table 8

Usage of leasing

\begin{tabular}{ccc|c|c|c} 
& & Frequency & Percent & Valid Percent & Cumulative Percent \\
\hline \multirow{3}{*}{ Valid } & Yes & 5 & 10.0 & 10.0 & 10.0 \\
\cline { 2 - 6 } & No & 45 & 90.0 & 90.0 & 100.0 \\
\cline { 2 - 6 } & Total & 50 & 100.0 & 100.0 & \\
\hline
\end{tabular}

Table 9

Correlations between usage of leasing among responders and information about leasing features

Usage of leasing or not

Info about features of leasing

\begin{tabular}{llcc}
\hline \multirow{3}{*}{ Usage of leasing or not } & \multicolumn{1}{c}{ Pearson Correlation } & 1 & $.437^{* *}$ \\
\cline { 2 - 4 } & Sig. (2-tailed) & 50 & .002 \\
\cline { 2 - 4 } & $N$ & $.437^{* *}$ & 50 \\
\cline { 2 - 4 } Info about features of leasing & .002 & 1 \\
\cline { 2 - 4 } & Pearson Correlation & 50 & 50 \\
\cline { 2 - 4 } & Sig. (2-tailed) & & \\
\hline
\end{tabular}

Note. ${ }^{* *}$ correlation is significant at the 0.01 level (2-tailed).

We see significant correlation $\mathbf{. 4 3 7}$ between those who answered negatively whether they have applied for a leasing or not and to the question whether they are familiar to leasing specificities. Only 4 responders out of 50 answered positively to the both questions at the same time. It approves the theory, that borrowers don't prefer leasing because of lack of information about this product.

Summarizing the survey results, it is obvious, that the state leasing support program is quite effective as all of the responders who used leasing, at the same time, are beneficiaries of the state leasing program. At the same time analysis on different countries' experience also supports this hypothesis. However, standard state support programs can be upgraded, which will put a lighter financial burden on the state and become a competitive alternative to bank loans for a large number of customers. Educational level of rural habitants and inconvenience about financing alternatives has been proved as an obstacle for much optimal financing of them. At the same time, mostly no alternatives were fixed for borrowers in the group.

\section{Discussion and Conclusion}

In almost every country in the world, governments support leasing as it is an effective tool for economic development. The development of leasing and its benefits for all parties of the contract can greatly affect the economy of Armenia \& other developing countries, as, for example, in agriculture and other fields of the economy professional equipment and technologies are out of date and need to be upgraded. Such equipment is mostly used by small \& medium-sized businesses $\&$ farms.

Despite the economic, social and political importance of the Armenian agricultural sector, its growth is still not sufficient because of number of reasons, mainly lack of efficient financing and technologies. The conclusions of this study show that agricultural finance is provided at a much lower level in Armenia than would be anticipated judging by the importance of this sector to the country's economy and GDP.

A hypothesis of leasing as an effective tool for rural area development has been proven. Several obstacles of leasing development have been taken out as insufficient information about leasing advantages, legal and regulatory gaps, weak government support etc.

Taking into consideration analysis of survey results, we see, that the public awareness about leasing, presentation of leasing benefits will make its use more accessible to customers as an alternative to bank loans. The applicability of leasing in Armenia is lacking and has great potential for development, but the answers to some questions suggest that the potential of 
leasing may be overestimated, such as the lack of collateral as a major lending problem for rural customers. Survey results also shows, that solving sole collateral issue cannot be satisfying condition for leasing development and awareness element and there can be beneficial synergies for government to implement specific development strategies through leasing (example of cooperatives). As a recommendation, specific leasing product can be designed by governments or private leasing companies with a specific list of manufacturers with their full contacts and specialization for rural habitants who want to buy equipment and provide exclusive service and price in case of buying leasing object from these manufacturers.

\section{Acknowledgements}

The study was financially supported by the Science Committee of the Ministry of Education, Science, Culture and Sports of the Republic of Armenia within the framework of the scientific project No. 19YR-5B026.

\section{References}

1. Christensen G. Sustainable, Inclusive Agriculture Sector Growth in Armenia: Lessons from Recent Experience of Growth and Contraction. Washington, DC: World Bank, 2017. Pp. 1-12.

2. Du Guerny J. Aids and agriculture in Africa: can agricultural policy make a difference? // Food Nutrition and Agriculture. 2000. No. 25. Pp. 9-12.

3. Fletcher M., et al. Leasing in development // Guidelines for emerging economies. IFC. 2005. No. 1. Pp. 1-12.

4. Brealey R. A., Myers S. C., Marcus A. J. Fundamentals of corporate finance. McGraw Hill, 2001. 640 p.

5. Grujić B. Financing of Agriculture of the Republic of Serbia from traditional to new models: doctoral dissertation. Belgrad, 2017. 152 p.

6. Podgornaya A. I., Abitov T. S. Leasing as a practical instrument for financial design in Russia // Journal of Environmental Treatment Techniques. 2019. T. 7. Special Issue. Pp. 1104-1107.

7. Namisiko P., Aballo M. Current status of e-agriculture and global trends: a survey conducted in TransNzoia County, Kenya // International Journal of Science and Research. 2013. T. 2. No. 7. Pp. 18-22.

8. The Food and Agriculture Organization of United Nations (FAO) [e-resource]. URL: http://www.fao.org/europe/news/detail-news/ru/c/1171123 (date of reference: 07.07.2020).

9. Mkhitaryan A. Leasing transactions in RA economic system. Yerevan: Limush publ., 2016. 102 p. (In Armenian.)

10. Civil Code of the Republic of Armenia. Articles 677-685. Yerevan, 1998. 429 p. (In Armenian.)

11. Gladilin V. A. Innovatsii v biznese, kak odin iz faktorov razvitiya ekonomiki [Business innovation as one of the factors of economic development] // Innovatsionnaya nauka. 2017. No. 1-1. Pp. 32-34. (In Russian.)

12. Novostnaya lenta ofitsial'nogo sayta Pravitel'stva Rossii [News feed of the official website of the Government of Russia] [e-resource]. URL: http://government.ru/news/39926/\#patrushev (date of reference: 07.07.2020). (In Russian.)

13. Gerasimova V. Role of leasing for sustainable development of the Russian economy // MATEC Web of Conferences. EDP Sciences. 2018. T. 170. P. 1-7.

14. Latruffe L., Desjeux Y. Common Agricultural Policy support, technical efficiency and productivity change in French agriculture // Review of Agricultural, Food and Environmental Studies. 2016. T. 97. No. 1. Pp. 15-28.

15. Lamine C., Niederle P., Ollivier G. Alliances and controversies in agroecological policy in Brazil and France // Natural Sciences Sociétés. 2019. T. 27. No. 1. Pp. 6-19. (In French.)

16. Popović S., Janković I., Stojanović Z. The importance of bank credits for agricultural financing in Serbia // Economics Poloprivlede. 2018. T. 65. No. 1. Pp. 66-70.

17. Jolović A., Njegovan Z., Čavlin M. Financing of the agriculture in Serbia: state and prospects // Economics Poloprivlede. 2014. T. 61. No. 1. Pp. 127-135.

18. Eremina O. I. Bankovskoe kreditovanie agrarnogo sektora ekonomiki [Bank lending to the agricultural sector of the economy] // Theory and Practice of Social Development. 2015. No. 24. Pp. 160-162 (In Russian.)

19. Das A., Patnaik N. M. Innovations in Agricultural Credit Disbursement and Payment Systems for Financial Inclusion in Rural India // International Journal of Current Microbiology and Applied Sciences. 2020. No. 9 (2). Pp. 1-7.

20. Hallam D. International investments in agricultural production // Land grabbing. 2009. No. 1. Pp. 1-6.

21. Kloeppinger-Todd R., Sharma M. (ed.). Innovations in rural and agriculture finance. Washington, DC: World Bank, 2010. T. 18.32 p.

22. Babaeva Z. S., et al. Agricultural lease as a form of financial support for the expanded reproduction of the agro-industrial complex // Espacios. 2017. T. 38. No. 62. Pp. 7-9.

23. Gyulgyulyan L., et al. Factors Influencing On Participation to Agricultural Cooperatives in Armenia // Regional Science Inquiry. 2019. T. 11. No. 1. Pp. 121-134.

24. Postanovlenie Pravitel’stva RF ot 31 marta 2020 g. № 391 “O vnesenii izmeneniy v gosudarstvennuyu programmu Rossiyskoy Federatsii "Kompleksnoe razvitie sel'skikh territoriy" [Russian Federation Governmnet decree from 31 March 2020 No. 391 "On amendments to the state program of the Russian Federation "Integrated development of the area of the territory"]. Moscow, 2020. 4 p. (In Russian.)

25. Official Website of Ministry of Justice of the Kyrgyz Republic [e-resource]. URL: http://minjust.gov.kg/en/ (date of reference: 06.07.2020). 


\section{Agrarian Bulletin of the Urals No. 03 (206), 2021}

26. Askarova A. K., Sydykov B. K. Deyatel'nost' kommercheskikh bankov i nefinansovykh organizatsiy na lizingovom rynke Kyrgyzskoy Respubliki: [Activities of commercial banks and non-financial institutions in the leasing market of the Kyrgyz Republic] // Economics, Entrepreneurship and Law. 2018. No. 8 (1). Pp. 41-49. (In Russian.)

27. Kholodilova A. Modern governmental instrument leasing activities // Norwegian Journal of Development of the International Science. 2018. No. 15-1. Pp. 24-28.

28. Akhmatova Zh. Kh., Gurfova S. A., Khochueva Z. M. Rol' bankov v privlechenii investitsiy v sel'skoe khozyaystvo Kabardino-Balkarskoy Respubliki [The role of banks in attracting investment in agriculture of the Kabardino-Balkarian Republic] // Finance and Credit. 2014. No. 14 (590). Pp. 21-27. (In Russian.)

29. Tilov A. A. Puti sovershenstvovaniya form i metody povysheniya konkurentosposobnosti lizingovykh kompaniy v Rossii [Ways of improving the forms and methods of increasing the competitiveness of leasing companies in Russia] // Management. 2020. T. 8. No. 1. Pp. 27-34 (In Russian.)

30. Tax code of the Republic of Armenia on making amendments and supplements, HO-321N. Yerevan, 2020. 3 p. (In Armenian.)

31. Ofitsial'nyy sayt Invest in Armenia [Official website of Invest in Armenia] [e-resource]. URL: http://investinarmenia.am/ $\mathrm{ru}$ /sector-overview-of-armenian-economy-ru (date of reference: 06.07.2020). (In Russian.)

\section{Authors' information:}

Aram S. Mkhitaryan ${ }^{1}$, candidate of economic sciences, associate professor of management department,

ORCID 0000-0002-3368-9831; mkhitaryan.aram@yahoo.com

${ }^{1}$ European University, Yerevan, Republic of Armenia 